\title{
Transfusion Therapy in Sickle Cell Disease
}

Kingsley Akaba ${ }^{1 *}$, Bassey O Bassey ${ }^{1}$, Idongesit Akpan ${ }^{2}$ and Ofonimeh Essien ${ }^{1}$

${ }^{1}$ Department of Hematology and Blood Transfusion, University of Calabar Teaching Hospital, Calabar, Nigeria

${ }^{2}$ Department of Hematology and Blood Transfusion, University of Uyo Teaching Hospital, Uyo, Nigeria

\begin{abstract}
Background: Blood transfusion is an important therapy in the management of sickle cell disease (SCD); especially in developing countries. Transfusion aids the restoration of the oxygen carrying capacity in patients with SCD and also prevents vaso-occlusion by dilution of the $\mathrm{Hbs}$ in circulation. However, there is paucity of information on transfusion as a therapy in the management of SCD.
\end{abstract}

Aim and objective: This study is aimed at reviewing the available publications on transfusion as a therapy for SCD management.

Materials and methods: Relevant literatures were searched on databases including PubMed, Google Scholar, Scopus, Cochrane and standard texts on haematology and transfusion medicine. The keywords used in the search are sickle cell disease, transfusion, simple and chronic transfusion, complications of transfusion, choice of blood for transfusion and guidelines for blood transfusion. The literatures gathered were reviewed, summarized and presented in this review.

Results: Blood transfusion is a cornerstone in the management of patients with SCD. The management of SCD patients requires a multidisciplinary approach with a great deal of commitment been required from all the experts. Although, many hazards are associated with blood transfusion, it is pertinent that proper care is taken in the handling and administration of blood and blood products.

Conclusion: Transfusion therapy still remains a cornerstone in SCD management and it tends to mitigate the severity and complication associated with SCD disorders. Adequate knowledge and information is needed by experts on the importance of transfusion therapy and its modalities in SCD.

Keywords: Transfusion; Therapy; Sickle cell disease

\section{Introduction}

Sickle cell disease (SCD) is a heterogeneous group of disorder, with a highly variable clinical spectrum. It is an autosomal recessive structural hemoglobin disorder [1]. The most prevalent form is sickle cell anemia (HbSS), which is due to inheritance of the sickle cell gene in a homozygous state. Other forms include the compound heterozygous forms in which the sickle beta globin gene is co-inherited with another abnormal hemoglobin gene such as $\mathrm{HbC}$ in $\mathrm{HbSC}, \beta$-thalassemia in $\mathrm{HbS} \beta$ thalassemia among others $[1,2]$.

SCD is the most common genetic disorder in Sub-Sahara Africa. Nigeria bears a high disease burden with an estimated prevalence of $1-3 \%$ of its population being affected by the disease. An estimate of $20-30 \%$ of her populace carry the sickle cell gene with a normal hemoglobin gene (carrier state) otherwise called the sickle cell trait. The disease burden in Nigeria differs slightly from one geographical region to another. Nwogoh et al. [3] reported the prevalence rate of SCD to be $2.4 \%$ and a $23 \%$ carrier state in Benin City. Madu et al. [4] reported a prevalence of $3.7 \%$ in a multi-center study in Nigeria.

Steady state is the crisis-free period extending from at least 3 weeks since the last clinical event and 3 months since the last blood transfusion to at least one week before the start of a new clinical event [5].

Blood transfusion still remains the major cornerstone of management of SCD; thus, the management of SCD patients requires a multidisciplinary approach including hematologists, orthopedic surgeons, urologists, nephrologist, cardiologists, nurses, psychiatric nurses and social worker [6]. The commitment of the experts, with a lot of other prophylactic and therapeutic measures which includes: appropriate and adequate analgesic, hydration, sedatives, haemopoietic stem cells transplantation, oxygen, hydroxyurea, folic acid, antioxidant and anti-coagulation as indicated [6].

Blood transfusion is said to restore the oxygen carrying capacity in patients with SCD and may also help to dilute the circulating Hbs, preventing vaso-occlusion [7]. It also suppresses the marrow from further production of sickle cells. There is paucity of information on transfusion as a therapy in SCD; this study is aimed at reviewing the available information on transfusion as a therapy in SCD.

\section{Modalities of Transfusion}

There are two major modalities of transfusion in SCD; Top-up (simple) and chronic transfusion.

\section{Top-up (Simple) transfusion}

Simple transfusion is a method for acute lower haemoglobin levels in acute sequestration crisis, aplastic crisis and chronic low haemoglobin level in chronic renal failure [7]. Simple transfusion is when a few units of bags of blood are given through small tube (blood given set) usually via the vein. Top up transfusion is frequently been used for SCD patients in need of acute transfusion [8-11]. The aim of top up transfusion is to raise the haematocrit and haemoglobin $\mathrm{A}(\mathrm{HbA})$

*Corresponding author: Kingsley Akaba, Department of Hematology and Blood Transfusion, University of Calabar Teaching Hospital, Calabar, Nigeria, Tel: 087 232055; E-mail: akaba_kingsley@yahoo.com

Received April 29, 2019; Accepted May 06, 2019; Published May 15, 2019

Citation: Akaba K, Bassey BO, Akpan I, Essien O (2019) Transfusion Therapy in Sickle Cell Disease. J Blood Lymph 9: 244.

Copyright: ( 2019 Akaba K, et al. This is an open-access article distributed unde the terms of the Creative Commons Attribution License, which permits unrestricted use, distribution, and reproduction in any medium, provided the original author and source are credited. 
level and also, at the same time dilute the HbS. Hence, increasing the oxygen carrying capacity of blood and also suppress the generation of sickle cell by the bone marrow $[12,13]$. Its disadvantage is that it could lead to increase blood viscosity that may precipitate crisis [13].

indication for top-up transfusion: The indications for Top-up transfusion includes [7,14-21]:

a. Acute splenic sequestration.

b. Aplastic crises.

c. Chronic hyperspleenism.

d. Chronic renal impairment.

\section{Transfusion to dilute the circulating sickle red blood cells} (Chronic transfusion)

Chronic transfusion is a kind of transfusion where an individual is transfused at 2-3 units within 3-4 weeks [7] with the therapeutic aim of reducing sickle haemogloin $[7,22]$. Chronic transfusion can be further divided into the conservative transfusion therapy which is aimed at maintaining the $\mathrm{Hb}$ level at 10 to $11 \mathrm{~g} / \mathrm{dL}$ with $50 \%$ reduction in $\mathrm{HbSS}$ (hypertransfusion) or the aggressive form (exchange blood transfusion) aimed at reducing sickle $\mathrm{Hb}$ level to less than 30\% [23]. Exchange blood transfusion can either be automated or partial exchange transfusion [7]. It has the advantage of rapid removal or sickle cell from the circulation, prevention of hyperviscosity, prevention of haemosiderosis, volume overload compare to hypertransfusion [24]; it also has the advantage of providing immunologic component at site of infection in patients with overwhelming infection [25].

Studies have showed that chronic transfusion has effectively help to prevent complication associated with Sickle cell anemia [7,26-31].

\section{Indication for chronic transfusion [32-40]:}

a. Cerebrovascular disease (first stroke prevention)

b. Repeat stroke prevention

c. Cerebral blood flow greater than $2 \mathrm{~m} / \mathrm{sec}$ highly predictive of stroke using Transcranial Doppler (TCD) ultrasonography

d. Recurrent episode of acute chest syndrome unresponsive to hydroxyurea

e. Recurrent bone pain crisis of more than three or more hospital admission and unresponsive to hydroxyurea therapy

f. Severe sickle cell disease with no HLA matching donor

g. Pregnant women with bad obstetric history and recurrent bone pain crisis

h. Chronic lugs disease

i. Chronic vital failure

j. Chronic leg ulcer

Guidelines for chronic Transfusion $[22,24,41]$ :

a. Initiation of chronic transfusion regimen in patients should be individualized

b. In clear terms, the decision to hyper transfuse should be well explained to the patients as well as their relatives

c. A well drafted therapeutic plan, easily comprehensible by all staff should be drafted d. An active blood bank with proper pre transfusion services

e. Pretransfusion laboratory investigations should include: Extended phenotyping and transfusion transmissible infections

f. Therapeutic goals such as the final haematocrit and the target sickle haemoglobin level should be set before each transfusion.

\section{Choice of blood for transfusion and monitoring}

The objective of chronic transfusion is lowering of HbSS level and it's effective if donor blood is confined to the normal AA genotype. Although, AS-genotype may be adequate thus improving blood flow but it complicate the monitoring of HbSS. Fresh blood should be advocated for since it stays longer in the recipients' circulation and reduce the frequency and duration of transfusion [42]. Chronic transfusion is usually monitored by $\mathrm{HbS}$ level, the post transfusion $\mathrm{Hb}$ is a secondary consideration. Abrupt changes in haematocrit level may complicate renal function and excessive transfusion may cause cerebral haemorrhage [43].

\section{Complications of blood transfusion}

Blood transfusion therapy despite being a major component in the management of SCD, also has its own draw backs. The knowledge of the limitation is very important to arm physicians with the necessary skill to ameliorate and curtail these complications. Complications of blood transmission are numerous and may be categorized either as: immunologic or non-immunologic, acute or chronic, early (occurring within 24 hours) or delayed (up to 4 weeks or longer).

Febrile non-hemolytic transfusion reaction (FNHTR): The most frequent hazard of transfusion is the febrile non-hemolytic transfusion reaction (FNHTR) $[44,45]$. This is as a result of the immunological exposure of an all immunized recipient to foreign antigen or donor white cells platelet, which leads to release of pyrogens. Furthermore, it could be attributed to leakage of cytokines from inflammatory cells in stored blood. FNHTR can also be found in multiparous women. It began within 30 minutes to an hour of commencement of transfusion, symptom include fever, chills, headache and itching.

Treatment: Discontinue the transfusion exclude other causes of fever, underlying disease in the patient, administer antipyretic, antihistamine leucodepleted red cell, premedication with antipyretic and transfusion should go slowly in subsequent transfusion [22].

Acute haemolytic transfusion reaction (AHTR): It is a serious life threatening complication of transfusion. It is due to incompatible blood components attributed to clinical errors. This results in immune response and activation of complement system leading to intravascular hemolysis. Furthermore, there is a massive release of inflammatory cytokines (cytokine storm). Also, there is a release of an anaphylatoxins both chemicals causes hypotension and acute renal failure. Moreover, the severe intravascular hemolysis triggers disseminated intravascular coagulopathy. AHTR is an emergency which is usually noted few minutes of starting the transfusion. Patients complains of heat and pains at the infusion site, loin pain, restlessness, fever, tachycardia, hypotension and bleeding [46].

Treatment: Transfusion should be stopped immediately. Replace plasma volume with crystalloid, manage complications, and investigate for AHTR, checking blood compatibility by repeating recipient's' preand post-transfusion blood samples on donor blood unit. Check for haemolysis, direct anti-globin test on pre- and post-transfusion sample, fibrin degredation product, D-dimer to rule out DIC and electrolyte, urea and creatinine, to rule out acute kidney injury [46]. 
Urticarias: These are attributed to allergens which the recipients have been previously sensitized with. The allergens are found in donor blood. Symptoms include: rashes, prutitus within minutes of transfusion. If patients are unresponsive to antihistamines, stop transfusion. Anaphylaxis is a severe form of allergy that is associated with immunoglobulin-A deficient recipients. Transfusion should be stopped immediately and patient is given adrenaline, chlorpheniramine/ promethazine, and hydrocortisone [22].

Delayed Haemolytic Transfusion Reactions: This is a serious complication and constituted $14-44 \%$ of patients with antibodies $[47,48]$. The symptoms include myalgia, severe bone pain, dark urine/ hemaglobinuria, increased anemia, and often reticulocytepenia and sometimes might mimick painful bone crisis. Delayed haemolytic reaction that occurs in aluminized individuals with low antibody titre often missed during investigation. Implicated antibodies include non-D Rh (E, C, and c), kell, duffy, and kidd antibodies [49,50]. With re-exposure to the antigen, secondary immune responses develop with antibody production manifesting about 7 to 10 days later with jaundice, fever, worsening anemia. Hemolysis is usually extravascular; antibody's screening and identification are very important for life threatening conditions or subsequent transfusion, the least incompatible blood is advocated for.

Recipient alloimmunization: It is a fatal complication that follows multiple transfusions. It reduces the outcome of successful transfusion. To mitigate this complication, extended red cell typing to identify significant blood group antigens including Rh, Kell, Kidd and duffy is very important $[41,51,52]$. For already alloimmunized patients, antigen or least incompatible blood unit should be transfused.

Iron overload: Each unit of blood used in transfusion contains about $225 \mathrm{mg}$ of iron. With the vigorous use and duration of chronic transfusion, there is increased tendency of iron deposition in the tissues (liver and heart). Attempts to mitigate this problem include: reducing the rate of iron accumulation by modifying transfusion method by voraciously reducing the target $\mathrm{HbS}$ level [52-54]. Automated red cell exchange may also be advocated for the use of chelating agent $[55,56]$.

\section{Conclusion}

Transfusion is an important component in the management of SCD particularly in developing countries with the aim of reducing the Hbs level and increasing the $\mathrm{Hb}$ level thereby, lessening the likelihood of SCD crisis and complication. The numerous hazards associated with this modality of treatment have made it unpopular and unrealistic. Therefore, a balance must be struck between its merit and demerits. The decision of transfusion is determined by several factors; the availability of resources for extending grouping, facilities for exchange transfusion, availability of effective chelating agent, other option of therapy such as hydroxyurea and failure to respond to hydroxyurea. All these factors contribute immensely to the reduction in transfusion therapy in sickle cell. Despite other disease modifying therapy in SCD, haemopoietic stem cell transplantation (HSCT) is the only potential curative form for now. Further efforts should be directed at educating and boosting the knowledge of specialists involved in the management of SCD patient on transfusion therapy as it remains the cornerstone strategic management especially in our environment.

\section{References}

1. Ashley-Koch A, Yang Q, Onley RS (2000) Sickle haemoglobin alleles and sickle cell disease. Am J Epidemol 151: 839-845.

2. Davies SC, Oni L (1997) Management of sickle disease. Br Med J 315: 655-660.
3. Nwogoh B, Adewoyin AS, Iheanacho OE, Bazuaye GN (2012) Prevalence of haemoglobin variant in Benin City, Nigeria. Annals of Biomedical Science 11: 60-64.

4. Madu AJ, Galadanci NA, Nalado AM, Garba KU, Fowodu OF, et al. (2014) Stroke prevalence amongst sickle cell disease patients in Nigeria: A multicentre study. Afr Health Sci 14: 446-452.

5. Akinola NO, Steven SM, Franklin IM, Nash GB, Stuart J (1992) Subclinical Ischaemic episode during the steady state of sickle cell anaemia. J Clin Pathol 45: 902-906.

6. Brozovic M, Davies S (1987) Management of sickle cell disease. Postgrad Med J 63: 605-609.

7. Serjeant GR (2016) Management of sickle cell disease: Challenges and risks of transfusion. Int J Clin Transfus Med 4: 109-119.

8. Wahl S, Quirolo KC (2009) Current issues in blood transfusion for sickle cel disease. Curr Opin Pediatr 21:15-21.

9. Buck J, Casbard A, Llewelyn C, Johnson T, Davies S, et al. (2005) Preoperative transfusion in Sickle cell disease: A survey of practice in England. Eur J Haematol 75: 14-21.

10. Yawn BP, Buchanan GR, Afenyi-Annan AN, Ballas SK, Hassell KL, et al. (2014) Management of sickle cell disease: summary of the 2014 evidencebased report by expert panel members. JAMA 312: 1033-1048.

11. Stanley AC, Christian JM (2013) Sickle cell disease and perioperative considerations: Review and retrospective report. J Oral Maxillofac Surg 71 : 1027-1033.

12. Koshy M, Weiner SJ, Miller ST, Sleeper LA, Vichinsky E, et al. (1995) Surgery and anesthesia in Sickle cell disease. Cooperative Study of Sickle Cell Diseases. Blood 86: 3676-3684.

13. Bischoff RJ, Williamson A, Dalali MJ, Rice JC, Kerstein MD (1988) Assessment of the use of transfusion therapy perioperatively in patients with sickle cell hemoglobinopathies. Ann Surg 207: 434-438.

14. Stevens MCG, Hayes RJ, Vaidya S, Serjeant GR (1981) Fetal hemoglobin and clinical severity of homozygous sickle cell disease in early childhood. J Pediatr 98: 37-41.

15. Pearson HA, Cornelius EA, Schwartz AD, Zelson JH, Wolfson SL, et al. (1970) Transfusion reversible functional asplenia in young children with sickle-cell anemia. N Engl J Med 283: 334-337.

16. Kinney TR, Ware RE, Schultz WH, Filston HC (1990) Long-term management of splenic sequestration in children with sickle cell disease. J Pediatr 117: 194199.

17. Rao S, Pang E (1982) Transfusion therapy for subacute splenic sequestration in sickle cell disease. Blood 60 (Suppl): 48a

18. Remmington T, Owusu-Ofori S (2017) Splenectomy versus conservative management for acute sequestration crises in people with sickle cell disease. Cochrane Database Syst Rev 11: CD003425.

19. Serjeant GR, Topley JM, Mason K, Serjeant BE, Pattison JR, et al. (1981) Outbreak of aplastic crises in sickle cell anaemia associated with parvoviruslike agent. Lancet 2: 595-597.

20. Serjeant BE, Hambleton IR, Kerr S, Kilty CG, Serjeant GR (2001) Haematological response to parvovirus B19 infection in sickle-cell disease. Lancet 358: 1779-1780.

21. Wright JG, Hambleton IR, Thomas PW, Duncan ND, Venugopal S, et al. (1999) Postsplenectomy course in homozygous sickle cell disease. J Pediatr 134 304-309.

22. Adewoyin A, Obieche JC (2014) Hypertransfusion Therapy in Sickle Cel Disease in Nigeria. Advances in Haematology 2014: 923593.

23. Natarajan K, Kutlar A (2006) Disorders of haemoglobin structure: sickle cel anaemia and related abnormalities in Williams Haematology 47: 667-700.

24. Vichinsky EP, Haberkern CM, Neumayr L, Earles AN, Black D, et al. (1995) A Comparison of Conservative and Aggressive Transfusion Regimens in the Perioperative Management of Sickle Cell Disease. N Engl J Med 333: 206-213.

25. Bischoff RJ, Williamson A, Dalali MJ, Rice JC, Kerstein MD (1988) Assessment of the use of transfusion therapy perioperatively in patients with sickle cell hemoglobinopathies. Ann Surg 207: 434-438. 
26. Charache S (1974) The treatment of sickle cell anemia. Archives of Internal Medicine 133: 698-705

27. Telen MJ (2001) Principles and problems of transfusion in sickle cell disease. Semin Hematol 38: 315-323.

28. Koshy M, Burd L, Wallace D, Moawad A, Baron J (1988) Prophylactic redcell transfusions in pregnant patients with sickle cell disease. A randomized cooperative study. N Engl J Med 319: 1447-1452.

29. Laulan JF, Bernard, Boivin P (1990) Systematic blood transfusions in adult homozygous sickle-cell anaemia. Presse Med 19: 785-789.

30. Cohen AR, Martin MB, Silber JH, Kim HC, Ohene-Frempong K, et al. (1992) A modified transfusion program for prevention of stroke in sickle cell disease. Blood 79: 1657-1661.

31. Lee MT, Piomelli S, Granger S, Miller ST, Harkness S, et al. (2006) Stroke prevention Trial in Sickle Cell Anaemia (STOP): extended Follow up and final result. Blood 108: 847-852.

32. Aliyu ZY, Tumblin AR, Kato GJ (2006) Current therapy of sickle cell disease Haematologica 91: 7-10.

33. Wayne AS, Kevy SV, Nathan DG (1993) Transfusion management of sickle cell disease Blood 81: 1109-1123.

34. Steinberg MH (1999) Management of sickle cell disease. N Engl J Med 340 1021-1030.

35. Vichinsky EP (2001). Current issues with blood transfusions in sickle cell disease. In: Seminars in Hematology, WB Saunders 38: pp. 14-22.

36. Adams R, McKie V, Nichols F, Carl E, Zhang DL, et al. (1992) The use of transcranial ultrasonography to predict stroke in sickle cell disease. $\mathrm{N}$ Engl $\mathrm{J}$ Med 326: 605-610.

37. Adams RJ, McKie VC, Hsu L, Files B, Vichinsky E, et al. (1998) Prevention of a first stroke by transfusions in children with sickle cell anemia and abnormal results on transcranial Doppler ultrasonography. N Engl J Med 339: 5-11.

38. Miller ST, Wright E, Abboud M, Berman B, Files B, et al. (2001) Impact of chronic transfusion on incidence of pain and acute chest syndrome during the Stroke Prevention Trial (STOP) in sickle-cell anemia. J Pediatr 139: 785-789.

39. Rogers R (2006) Review: Clinical transfusion management in sickle cell disease. Immunohematology 22: 126-131.

40. National Health Service (2010) Sickle Cell Disease in Childhood Standards and Guidelines for Clinical Care, NHS Sickle Cell and Thalassaemia Screening Programme (2ndedn), London, UK, pp:1-90.

41. Sickle Cell Society (2008) Standards for the clinical care of adults with sickle cell disease in the United Kingdom, Chapter 6: Blood transfusion, Sickle Cell Society, 54 Station Road, London, NW10 4UA, pp: 69-80.

42. Corash LM, Piomelli S, Chen HC, Seaman C, Gross E (1974) Separation of erythrocytes according to age on a simplified density gradient. J Lab Clin Med 84: $147-151$

43. Serjeant G (2003) Blood transfusion in homozygous sickle cell disease-a cautionary tale. Lancet 361: 1659-1660.

44. Gwalam BA, Borodo MM, Dutse Al, Kaliya-Gwarzo A (2012) Patterns of acute blood transfusion reactions in Kano, north-western Nigeria. Niger J Basic Clin Sci 9: 27-32.

45. Arewa OP, Akinola NO, Salawu L (2009) Blood transfusion reactions: evaluation of 462 transfusions at a tertiary hospital in Nigeria. Afr J Med Med Sci 38: 143-148.

46. Adewuyi JO (2007) Blood group serology, In: Companion to Practical Haematology 10: 74-84.

47. Cox JV, Steane E, Cunningham G, Frenkel EP (1988) Risk of alloimmunization and delayed hemolytic transfusion reactions in patients with sickle cell disease. Arch Intern Med 148: 2485-2489.

48. Vichinsky EP, Earles A, Johnson RA, Hoag MS, Williams A, et al. (1990) Alloimmunization in sickle cell anemia and transfusion of racially unmatched blood. N Engl J Med 322: 1617-1621.

49. Bashawri LAM (2007) Red cell alloimmunization in sickle-cell anaemia patients Eastern Mediterranean Health Journal 13: 1181-1189.

50. Yazdanbakhsh K, Ware RE, Noizat-Pirenne F (2012) Red blood cell alloimmunization in sickle cell disease: pathophysiology, risk factors, and transfusion management. Blood 120: 528-537.

51. Al-Saeed HH, Al-Salem AH (2002) Principles of blood transfusion in sickle cel anemia. Saudi Med J 23: 1443-1448.

52. Mid-Atlantic Sickle Cell Disease Consortium (MASCC) Practice Guidelines (2001) Chronic transfusion in children with sickle cell disease, In: Sickle cell disease in children and adolescents: Diagnosis, guidelines for comprehensive care and protocols for management of acute and chronic complications, pp: $32-36$

53. Miller ST, Jensen D, Rao SP (1992) Less intensive long-term transfusion therapy for sickle cell anemia and cerebrovascular accident. J Pediatr 120 54-57.

54. Cohen AR, Martin MB, Silber JH, Kim HC, Ohene-Frempong K, et al. (1992) A modified transfusion program for prevention of stroke in sickle cell disease. Blood 79: 1657-1661.

55. Kim HC, Dugan NP, Silber JH, Martin MB, Schwartz E, et al. (1994) Erythrocytapheresis therapy to reduce iron overload in chronically transfused patients with sickle cell disease. Blood 83:1136-1142.

56. Hilliard LM, Williams BF, Lounsbury AE, Howard TH (1998) Erythrocytapheresis limits iron accumulation in chronically transfused sickle cell patients. Am J Hematol 59: 28-35. 